\title{
O Profissional do Direito e a Engrenagem Administrativa
}

\section{Corsíndio Monteiro da Silva}

O servidor público vive dentro de um mundo de fenômenos jurídicos. Toda a sua vida funcional se inscreve ou se realiza dentro de um ordenamento jurídico positivo de que ele é artífice e, muitas vezes, destinatário. Qualquer norma que se aciona no âmbito da Administração Pública tem inequívoca repercussão jurídica, direta ou indiretamente.

Daí por que dificilmente poderá a Administração prescindir do profissional do Direito se quiser bem administrar, inclusive com justiça.

Como para aplicar ou entender o Direito é necessário bomsenso, tem-se concluído que basta se tenha essa qualidade para exercer o Direito. Ora, bom-senso é coisa que ninguém julga ter menos que ninguém, já o afirmara Descartes ironicamente, mas nem por isso todos nós conhecemos o Direito. Não basta bom-senso para se conseguir bons colaboradores de normas legais, bons intérpretes da lei ou bons aplicadores do Direito.

Ter o sentido do que é justo não faz de alguém conhecedor, só por isso, do que seja Direito.

A técnica em si, em matéria administrativa, é de pouca ou nenhuma valia ou eficácia se não atendida pela visão de conjunto daquele que possui formação jurídica.

Somente o técnico em Administração Pública não equaciona ou resolve a generalidade dos problemas administrativos. $E$ isto é de fácil verificação, pois que vimos testemunhando, de certo tempo a esta parte, o que são, por exemplo, normas legais 
redigidas sem audiência dos que conhecem técnica legislativa, vale dizer, sem audiência dos profissionais do Direito, ou, ainda, dos sem nenhuma vivência administrativa ou jurídica.

É claro que a vivência e a convivência têm feito de técnicos em Administração Pública bons elaboradores de normas legais e até mesmo lúcidos intérpretes, embora isso não invalide o que aduzimos, pois talento e receptividade para conhecimentos especializados hauridos em constante e diuturna convivência com bons profissionais não constituem acontecimento normal. Talento, sensibilidade e espírito de observação suprem, de muito, não há dúvida, a falta de formação profissional. Tais virtudes, porém, não são constantes entre servidores públicos comuns, nem mesmo entre técnicos.

A experiência no trato da coisa pública nos revela que o profissional do Direito é peça imprescindível na engrenagem administrativa; é figura quase obrigatória em uma série de atividades que requerem formação própria e contacto continuado com o mundo jurídico: conhecimentos gerais da Ciência Jurídica, alguma vivência forense para fixação de certos conceitos e conhecimento, inclusive, da dinâmica do Direito e de sua nomenclatura, não só para empregá-la como para entendê-la; conhecimentos específicos de conformidade com o ramo do Direito para o qual sua atribuição mais o solicite; conhecimentos das leis administrativas e da principiologia do Direito Administrativo, além de, se possível, alguma cultura geral.

$\mathrm{Na}$ elaboração de projeto de leis, grande tem sido a colaboração do profissional do Direito, ou mais propriamente, do Bacharel em Direito, mesmo que esse Bacharel ocupe cargo para cujo ingresso ou provimento não se exija, ou não se exigiu, diploma de Bacharel em Ciências Jurídicas e Sociais.

Quando se prescindiu dessa colaboração, foi isso logo notado e continua sendo: em geral, tal aconteceu, e ainda acontece, quando a autoridade administrativa não dá maior crédito ao profissional do Direito porque vê nele, dentro de preconcebida atitude, um complicador das coisas simples ou dentro de uma imagem que vem sendo elaborada de há muito pela rabulice de alguns colegas ou pela criminosa incompetência de outros, assim servindo à idiossincrasia gratuita de alguns tecnocratas que se arvoraram em donos da Administração Pública.

Tirante o vezo de igualar por baixo, porque alguns Bacharéis, ou Assistentes Jurídicos, ou Procuradores, na sua maioria 
readaptados, são "incompetentes" ou "quase analfabetos" no que há um pouco de exagero -, não se há de concluir que todos os Bacharéis, todos os Assistentes Jurídicos, todos os Procuradores são ineficientes, desidiosos, incapazes, confusos, sofistas, ociosos, ou que se abra mão do profissional do Direito na vida administrativa.

A título de ilustração dessa imagem de que "goza" o Bacharel, seja-nos permitido lembrar episódio que conosco ocorreu nos idos de 1958, no DASP: estava eu examinando processo de interesse de um Vice-Almirante Médico, da Reserva Remunerada, que teria sido amparado pela norma constante do artigo 24 do Ato das Disposições Constitucionais Transitórias. Nos termos do entendimento até então dominante sobre o assunto, a solução a que me levava o estudo do processo me parecia injusta para o interessado sem deixar de ser prejudicial à Administração. Enquanto demorava a encontrar solução equânime e mesmo viável, teve o interessado notícia de que seu processo estava sendo estudado por determinado funcionário que se encontrava "na sala ao lado". Não guardou ele o nome arrevezado do servidor mas "sentira" que se tratava de Bacharel... Dirigiu-se incontinente para a sala em que estávamos. Aos primeiros passos, parou, ficando sem saber ao certo a quem dirigir-se. Extrovertido, disse bem alto: "Eu me chamo Fulano de Tal. Tenho um processo de meu interesse pessoal que está rolando há cerca de um ano e soube que agora está aqui sendo estudado por um Bacharel cujo nome não consegui guardar...". Como a nos decifrar ou para nos surpreender por um simples gesto, passeou o olhar inquiridor por todos nós. Freado pelo nosso silêncio, pois que nada tínhamos que tratar diretamente com o interessado, havendo mesmo uma determinação superior para não se dizer quem estava "informando" qualquer processo, foi-nos dando ele as costas vagarosamente sem tirar de nós os olhos crescidos e vigilantes, enquanto ia dizendo como que rezando: "Meu Deus, meu processo está com um Bacharel! Tenho medo dos Bacharéis, eles complicam tudo!" E foi saindo, cabisbaixo!

Dias depois, o parecer que o "Bacharel" proferiu solucionou de vez o problema, solução que, na prática, também atendia ao interesse da Administração, sendo alterada, inclusive, a redação do decreto... Não voltou o interessado para agradecer (o que evidentemente seria desnecessário) nem para se penitenciar da injustiça que cometera, pois que foi o Bacharel mesmo 
que encontrara a solução para um problema que resultara da aplicação de uma norma mal regulamentada por um não-Bacharel, havia cerca de quatro anos. E aquele Bacharel solucionou não só esse como muitos outros problemas quase insolúveis que outros, que não eram Bacharéis, não quiseram ou não puderam resolver...

A questão, na verdade, não é ser ou não ser Bacharel. É ter ou não ter competência; ter ou não ter disposição para o trabalho ou para acertar; ter ou não ter boa vontade para resolver os assuntos da melhor maneira possível, sem desservir a Administração mas também sem atropelar os justos interesses dos servidores ou administrados.

O profissional do Direito, estudioso e afeito ao trato dá literatura jurídica e da hermenêutica, sabe ver o assunto que examina em seus mais variados aspectos, além de suas repercussões, positivas ou negativas.

Não já a malícia mas o faro, revela o profissional a serviço de uma idéia que se quer convertida em norma. Quando da interpretação da norma ou da aplicação do Direito, revela-se o olho clínico que faz ressaltar o principal, desvelar o ponto nevrálgico de uma questão, de uma dúvida, a solução para um impasse muitas vezes criado por construções aparentemente bem postas - e que até impressionam - mas, quase sempre, cerebrinas aos olhos de quem sabe ver e distinguir.

Não raro, surpreendemos processos volumosos com pareceres os mais desencontrados, com argumentação muitas vezes cerrada sobre aspectos secundaríssimos ou mesmo irrelevantes do problema a resolver, que em nada aproveitam para deslinde da matéria.

Aí é que surge o que tem olhos de ver, o que vai ao ponto e o encara de frente, examina, esclarece, situa, argumenta e constrói, com a tecitura de sua dialética, a solução adequada para a dúvida que gerou a controvérsia aparentemente insolúvel e sem remédio.

$\mathrm{Na}$ elaboração de regulamentos, é inestimável - e até mesmo indispensável - a colaboração efetiva do Bacharel em 
Direito, pois que o regulamentador é, a rigor, o primeiro intérprete do preceito legal. E o intérprete da norma legal tem que estar familiarizado com os princípios da hermenêutica jurídica e com os princípios gerais de Direito.

É evidente que o técnico em Administração Pública emprestará, também ele, colaboração inestimável, mas o profissional do Direito tem, ou, pelo menos, é de presumir que tenha, o domínio de certas regras jurídicas que devem ser e são aplicadas em cada norma articulada. Tem esse domínio como formação profissional, como conscientização profissional, como sua segunda natureza.

Não basta, realmente, se seja Bacharel em Direito, Advogado, Procurador, ou Professor de Direito, para a colaboração eficiente à Administração Pública, embora com o só fato de ter formação jurídica já constitui meio-caminho andado para se formar o bom colaborador ou o bom servidor público. Muitas vezes é uma questão de motivação, que praticamente não existe em grandes áreas da Administração Pública, principalmente com referência aos Bacharéis.

Faz-se mister a especialização através da eleição de um campo de conhecimentos para nele se aprofundar e, por fim, dominá-lo, tanto quanto possível, não bastando o conhecimento da doutrina e, sim, de todo o ordenamento jurídico positivo que interessa à Administração Pública ou ao seu agente.

Sirva de ilustração o fato de que as Universidades brasileiras nem sempre se valem de seus Catedráticos de Direito Administrativo para solucionar, muitas vezes, pequenas dúvidas de matéria administrativa, dentro do âmbito, por exemplo, de assunto de pessoal, de interpretação de norma que diz respeito a funcionário público, mesmo porque neste assunto também se requer especialização e alguma vivência.

Isto porque os mestres ilustres vivem a pairar no olimpo das abstrações da Ciência Jurídica, descuidados da realidade prática em que vivemos, e não se dedignam descer o olhar cá para baixo, para estas miseriazinhas do cotidiano, que estas o DASP as resolverá, por certo, quando consultado.

Neste capítulo, e divagando um pouco, não será demais observar o divórcio existente entre a Cátedra e a Prática, razão 
por que dificilmente temos Bacharéis aptos a desempenhar, de imediato, isto é, assim que saem das universidades, função pública, sem que antes, seja através de estudos especializados, seja por meio de alguma experiência que, ocasionalmente, possa ter acontecido, se dedique, por algum tempo, ao domínio do assunto em verdadeiro esforço de autodidata. Da Cátedra, quando muito se traz uma remotíssima informação acadêmica. Na Repartição, aprenderá por esforço próprio e a duras penas. O coeficiente pessoal se impõe aqui de maneira irrecusável.

$\mathrm{O}$ acadêmico recém-chegado das universidades nada traz a não ser a informação muito por alto do Direito Administrativo, Cadeira que deveria ser desdobrada em dois anos letivos como acontece com o Direito Penal. E a parte especial deveria ser ministrada com a assistência obrigatória de um profissional experimentado, com aulas dinâmicas à vista de casos para resolver ou comentários dos já resolvidos, com críticas objetivas etc.

Basta se perlustre manuais, cursos e tratados de Direito Constitucional e, especialmente, de Direito Administrativo Brasileiro para se sentir, de logo, dentro do assunto do regime jurídico do servidor público, um tal qual distanciamento da matéria apesar de sua relevância e do inequívoco saber de seus autores em outras áreas, quase sempre eminentes titulares de Cátedras universitárias. Não é raro deparar-se com uma série de assertivas em torno de assunto já superado, confusão, informação deficiente de certos institutos, inteiro alheamento à realidade dos fatos e à própria bibliografia especializada.

Neste sentido, muitos autores se comprazem em louvar-se em mestres de outras terras, numa fastidiosa e inútil demonstração de erudição, incapazes de andar o espaço de uma linha impressa sem a muleta ou o respaldo, como se costuma dizer, de um autor estrangeiro, de nomeada, ou não, mas desde que estrangeiro, cometendo, outros, a proeza de tratar demoradamente de certos assuntos específicos de nosso Direito Administrativo sem dignar-se de referir a seus cultores nacionais especializados, ao menos para contraditá-los. Se na parte geral se valem dos mestres estrangeiros, mal não ficaria, para a parte especial, tomar conhecimento do que vai aqui pela casa a dentro, pesquisando ou se inteirando da bibliografia indígena referente ao assunto do dia-a-dia de nossa Administração. 
Sendo o Direito Administrativo um dos ramos do Direito mais importantes no momento histórico porque passamos, com uma tendência a se desenvolver cada vez mais por força da ingerência do Estado em novas áreas, é desolador ver que os acadêmicos ficam e permanecem nas abstrações jurídicas e filosóficas, quando muito, passando em brancas nuvens sobre esse capítulo da maior expressão no mundo, inclusive, da cultura jurídica atual.

É verdade que a Administração Pública, grandemente interessada na preparação de uma elite, pode e deve preparar novos elementos dentro de um processo novo de recrutamento ou seleção, sem esquecer dos que já servem, fazendo um trabaIho de reciclagem de conhecimentos dentro de dinâmica moderna de ensino.

Quanto à imprescindibilidade do Bacharel em Direito, não é de subestimar a defesa que ele faz em Juízo dos interesses administrativos e do Erário. Os que fazem essa defesa são exatamente os Bacharéis em Direito através das Procuradorias e do chamado Serviço Jurídico da União, e devem eles estar não só a par da Jurisprudência dos Tribunais, como da legislação em que se engolfa a Administração Pública, além de dar uma assistência ao andamento dos processos. Neste sentido, indisfarçável é, também, a contribuição valiosa dada pelos Assistentes Jurídicos e pelos Consultores Jurídicos dos Ministérios e do DASP na instrução dos processos ou em informação em mandados de segurança, que servem, quase sempre, de verdadeiro suporte para a Procuradoria da República na defesa dos interesses da União em Juízo. Sem esse suporte, dificilmente poderiam desincumbir-se a contento de suas tarefas a Consultoria-Geral da República, seja a própria Procuradoria-Geral da República.

E quanto aos Bacharéis que emitem pareceres em cada caso? Sua tarefa é menos meritória? As decisões das autoridades não são em sua quase totalidade baseadas em tais pareceres?

Mas há quem olha com desdém os pareceristas, e isto porque desconhece a responsabilidade que pesa sobre seus ombros quando emite um parecer que é aprovado pela autoridade competente. Se a autoridade errou, foi porque o parecerista o induziu em erro. Se acertou, o mérito deveria ser, também, do parecerista. $\mathrm{Na}$ base de toda decisão há, em concreto, o entendimento jurídico de um parecerista. $\mathrm{E}$ a autoridade tem que ter confian- 
ça no parecerista que tudo deve fazer por não desmerecer dessa confiança porque isso faz parte de sua consciência profissional.

No Estado de Direito, a que Werner Goldschmidt prefere chamar Regime de Justiça, não basta que a autoridade administrativa decida a favor ou contra determinada pretensão e, sim, que fundamente o seu entendimento. Nesse sentido, o parecerista é a alma das decisões administrativas: é o que ele indica ou sugere que anima a vontade da autoridade e que passa a constituir a solução a ser dada em cada caso que se apresenta diariamente à Administração Pública.

De passagem se diga: quantos técnicos em Administração não conseguiram nomeada somente por assinarem pareceres feitos por Bacharéis em Direito! Por muito tempo isto aconteceu, e ainda acontece, na Administração Pública, não passando muitos funcionários altamente qualificados de simples e malpagos escribas, servindo para projetar nomes de muitos tecnocratas - não raro medíocres - que, hoje, ainda se voltam contra os profissionais do Direito e que procuram arrebatar-Ihes velhas e sofridas conquistas, atribuindo-lhes, ainda, males crônicos de uma Administração obsoleta que só agora parece acordar de sua letargia!

Aos que criticam os pareceristas é de perguntar: como solucionar os casos que surgem cada dia ao administrador? Teria o computador eletrônico condições para resolver problemas de ordem muitas vezes subjetiva, como dar o exato entendimento de uma norma legal?

Nunca se fez tão necessária a presença do profissional do Direito como agora; inclusive, como afirmou um mestre, para coerência de orientação e em respeito pelos valores éticos superiores, uma vez que o trato do Direito, como lembrava Rui, acostuma a aceitar a controvérsia, a respeitar o adversário, a equidade, a acatar a lei, a considerar os problemas sociais e individuais à luz maior da justiça (Luís A. Martins - Artigo em O Estado de São Paulo, de 26 de agosto de 1971). No mundo moderno, o Bacharel em Direito é o artífice da paz social e peça vital na engrenagem administrativa, para que possa haver uma Administração clara em seus objetivos e justa em seus propósitos.

O que cumpre à Administração Pública é valorizar esses profissionais, motivando-os a seu serviço e conferindo a eles 0 status merecido. 